\title{
Preventive youth health care in 11 European countries: an exploratory analysis
}

\author{
Rosemarie C. N. Wieske • Marianne G. Nijnuis • \\ Bettie C. Carmiggelt $\cdot$ Margreet M. Wagenaar-Fischer • \\ Magda M. Boere-Boonekamp
}

Received: 17 July 2010/Revised: 6 September 2011/Accepted: 12 September 2011/Published online: 29 September 2011

(c) The Author(s) 2011. This article is published with open access at Springerlink.com

\begin{abstract}
Objective To systematically identify similarities and differences in the way preventive youth health care (YHC) is organized in 11 European countries.

Method Questionnaire survey to EUSUHM (European Union for School and University Health and Medicine) representatives.

Results The greatest similarities were found in the age range of the YHC target group and the separation of curative and preventive services. Croatia, Germany and Switzerland show the greatest differences when compared to other European countries, for example, in the access to medical records, YHC professional input and the number of examinations, immunizations and screenings. In eight countries YHC is financed by national insurances or taxation. In Germany, FYR Macedonia, the Netherlands,
\end{abstract}

R. C. N. Wieske

Health Sciences, University of Twente, Enschede,

The Netherlands

M. G. Nijnuis

Youth Department, Municipal Health Services, Zeist,

The Netherlands

B. C. Carmiggelt

Dutch Child Health Knowledge Center, Utrecht,

The Netherlands

M. M. Wagenaar-Fischer

TNO, Leiden, The Netherlands

M. M. Boere-Boonekamp ( $\square)$

Health, Technology and Services Research,

University of Twente, P.O.Box 215, 7500, AE,

Enschede, The Netherlands

e-mail: m.m.boere-boonekamp@utwente.nl
Russia and Switzerland, different forms of financing exist in parallel.

Conclusion The results should be interpreted as a preliminary step in mapping organizational features of YHC in Europe.

Keywords Preventive youth health care . Developmental care Health care system . Health care comparison

\section{Introduction}

There are remarkable differences in the health situation of the youth in European countries. According to the Convention on the Rights of the Child, which is ratified by all European countries, every child in Europe has the same rights to the highest attainable level of health care (Office of the United Nations High Commissioner for Human Rights 2004; UN General Assembly 1989) Although child mortality rates, excepting suicide, have decreased over the years in all countries, a large variation still exists (World Health Organization Regional Office for Europe 2009). A health gap has developed between East and West European countries and there are striking inequalities across the countries in health status and access to health services, with over ten-fold differences in infant and child mortality rates (Bobak and Marmot 1996; Vågerö 2010; World Health Organization 2005). East European countries show higher cause-specific mortality rates than West European countries for infectious and parasitic diseases and external causes of injuries, such as transport accidents and poisoning (World Health Organization Regional Office for Europe 2009). Primary (youth health) care helps to prevent illness and death, and effective youth health care (YHC) 
prevention programs may reduce high mortality rates (Starfield et al. 2005; Christian et al. 2010).

The term YHC is derived from the Dutch and Flemish research and practice. The Dutch Child Health Knowledge Center (2010) defines YHC as preventive care which concentrates on the growth and development of the child, to prevent the child from severe health problems. In the United States the term (preventive) well-child care is practiced, covering: (1) health supervision, including anticipatory guidance on nutrition, sleep, elimination, discipline, preventing injuries, etc., (2) developmental supervision and milestones, and school performance, (3) child and family psychosocial assessment, (4) care coordination (oversight of referrals to needed community-based resources or services), and (5) immunization(s), physical examination and additional screening (height, weight, etc.) (Kuo et al. 2006).

In Europe, each country organizes YHC in a different way. Differences in the organization of preventive care may contribute to the differences in child mortality rates. Comparisons of specific aspects of health care of countries were described before (European Society of Ambulatory Pediatrics (ESAP) 2006; Kuo et al. 2006; Mackenbach et al. 2008; RIVM 2008), but a comparison specifically of YHC approaches in European countries is lacking.

The objective of this research was to provide a preliminary framework to identify similarities and differences in the organization and delivery of preventive YHC in countries who are the members of the European Union for School and University Health and Medicine (EUSUHM). The EUSUHM aims to improve and develop health services in schools and universities across European countries through encouragement and fostering; and to keep member associations and individual members informed regarding the changing pattern of YHC in different countries. The organization has 13 member countries (www.eusuhm.org) (EUSUHM 2004). The results of this study are a first step to categorize YHC systematically in order to conduct, next, more analytical studies on the link between YHC characteristics and youth health status. Only a selection of the results is presented in this short report. To gain access to the full results, please contact the last author (m.m.boereboonekamp@utwente.nl).

\section{Methods}

The research was restricted to the 13 countries who are the member of the EUSUHM. Data to identify similarities and differences in YHC systems were collected by means of questionnaires. Components of the primary care framework proposed by Macinko et al. (2003), tailored to the YHC by Kuo et al. (2006), were adapted to measure structural and practice features in the organization of preventive YHC.
Because of our cooperation with the Dutch Association of YHC Doctors (AJN) and the Dutch Child Health Knowledge Center, the activities within preventive YHC that were to be investigated were chosen based on the Dutch National Youth Health Service Package. This service package describes a set of activities to be performed for the target group of YHC (Ministry of Health, Welfare and Sport (Ministerie van Volksgezondheid, Welzijn en Sport) 2002). Questions were formulated based on literature (Kuo et al. 2006; Macinko et al. 2003; Ministry of Health, Welfare and Sport (Ministerie van Volksgezondheid, Welzijn en Sport) 2002) and in close consultation with experts of the AJN, the Dutch Child Health Knowledge Center and the presidents of the AJN and the EUSUHM Executive Commission. The questions were divided in three categories:

- Structural features: the organization of YHC including target group, financing, YHC professionals inputs, etc.;

- Practice features: the delivery of YHC including coordination, national guidelines, record-keeping, etc.;

- Basic activities of YHC including monitoring and detection, immunizations, screenings, etc.

A first (basic) questionnaire consisting of seven questions was sent in March 2009, a second more extensive questionnaire (59 questions) in May 2009. The questionnaires were sent by e-mail to the representative of each of the 13 EUSUHM member countries: Belgium (Flemish region), Croatia, Estonia, Finland, Germany, Hungary, FYR Macedonia, the Netherlands, Norway, Russia, Slovenia, Switzerland and the United Kingdom. The representative was doctor-chairman of a (national) YHC organization, i.e. a Society for YHC, a Society for School and University Medicine, a School Healthcare Foundation or an association of doctors working in YHC services. Questionnaires could be answered by the representatives themselves or in collaboration with colleagues. The collected data were processed and a preliminary report was sent back to the respondents for verification in March 2010.

To assess similarities and differences we made use of a qualitative method. All data relevant to each framework category (structural, practical or basic activities) were examined and categorized by two of the authors (MN, $\mathrm{RW})$. In case of disagreement, the concerning respondent was consulted for extra information regarding the question and/or all authors were consulted to reach an agreement.

\section{Results}

Completed and revised questionnaires were returned by respondents in 11 EUSUHM countries. No response was received from Norway and the United Kingdom. A selection of the results is discussed in the section below. 
Structural features: the organization of Youth Health Care

In eight countries the YHC target group includes all children $0-19$ years of age. Croatia offers YHC until the regular graduation of adolescents from university, Switzerland until the age of 16, Germany until 12.

All respondents, with the exception of the one German, reported that the YHC sector is organized nationally. In Germany, competences are divided between the national government, states and municipalities.

In eight countries the YHC is distributed through specific YHC organizations or subdivisions of the public health care. In Hungary and the FYR Macedonia, YHC is provided by different types of health professionals, such as pediatricians, general practitioners and school doctors. Germany has two different types of care delivery: in the case of insurance companies, care delivery is managed by pediatricians and doctors contracted by the health insurers. In the case of taxes, care is delivered through subdivisions of the public health system. Switzerland has also a dual system: YHC is offered by (private) pediatricians or, if available, by school health services.

In eight countries the $\mathrm{YHC}$ is financed by national insurances or taxation. In Germany, FYR Macedonia, the Netherlands, Russia and Switzerland, different forms of financing exist in parallel. Preventive examinations and immunizations are free of charge in all countries, except Switzerland.

Different combinations of professional inputs exist per country. In most countries the pediatrician and GP play a central role. Belgium and The Netherlands represent particular examples with specialized YHC doctors, YHC nurses and multidisciplinary teams.

\section{Practice features: the delivery of Youth Health Care}

Preventive and curative cares for children are separated in eight countries. In Switzerland a separation only exists in areas with school health services, while there is no separation in Estonia and Slovenia.

In most countries, contacts between preventive YHC and curative health care are restricted to the exchange of data. Finland is an exception, stating that structural contacts, usually face-to-face, are common.

Interdisciplinary systems that permit consultations about complicated problems among school children exist in Belgium, Croatia, Finland, FYR Macedonia and The Netherlands.

National guidelines for the YHC staff on such topics as immunizations and screenings exist in all EUSUHM countries, except for Germany and Switzerland. In most countries the guidelines are promulgated by the Ministry of
Health. In Croatia, FYR Macedonia and the Netherlands, the guidelines are owned and published by a (joint) national board.

Evidence-based interventions are practiced in nine EUSUHM countries. The Ministries of Health, national boards or national institutes of the countries decide whether or not interventions are labeled 'effective'. Finland and Germany do not have a focus on evidence-based practices. In Switzerland the interventions are covered by health insurers when the evidence-base has been approved of by a special commission.

YHC professionals in all countries keep individual records of the care provided. The use of electronic records is rising in West European countries; this is not the case in East European countries such as Slovenia, FYR Macedonia and Croatia. Differences in record-keeping relate to the shared use of the record by preventive and curative services and the extent to which access is provided to health care professionals, schools and parents.

\section{Basic activities of Youth Health Care}

Respondents in ten countries reported that 'a basic range of duties and/or activities' (national youth health service package) had been developed for the YHC in their country. Only Germany does not have such a package at the national level.

As a part of the service package, the health status of the children and deviations in growth or development are measured and identified in all countries. The initiative for consultations related to monitoring and early detection is taken by YHC organizations; in nearly all countries a standard call-up scheme is utilized for this purpose. In Finland parents can also take the initiative. In Germany the responsibility for attending consultations is left with the parents. According to the respondent, this leads to lower coverage in their program among the lower socio-economic groups of the population. In Switzerland school health services work with a call-up scheme; private pediatricians have a planned timetable for examinations whereby the doctor recommends the next consultation. Table 1 lists the number of examinations per age group in each country.

In all countries YHC performs immunizations and programmatic screenings of asymptomatic children for specific disorders. Table 1 summarizes the immunizations and screenings performed.

Epidemiological research based on YHC surveillance data is a regular activity of YHC in almost all countries. In Switzerland the research is restricted to monitoring the body mass index of children by some of the school health services. 
Table 1 Basic activities youth health care: number of examinations, immunizations and screenings performed in 11 European countries, 2009

\begin{tabular}{|c|c|c|c|c|c|c|c|c|c|c|c|}
\hline Country & $\mathrm{BE}$ & $\mathrm{CH}$ & $\mathrm{DE}$ & $\mathrm{EE}$ & FI & HR & $\mathrm{HU}$ & MK & NL & RU & SI \\
\hline \multicolumn{12}{|l|}{ Number of examinations ${ }^{\mathrm{a}}$} \\
\hline $5-10$ & & & + & & & & & & & & \\
\hline $11-15$ & & + & & & & + & + & + & & & + \\
\hline $16-20$ & + & & & & & & & & + & & \\
\hline$\geq 21$ & & & & + & + & & & & & + & \\
\hline \multicolumn{12}{|l|}{ Immunizations } \\
\hline Bacillus Calmette-Guérin & & & & & & + & & + & & + & \\
\hline Diphtheria & + & + & + & + & + & + & + & + & + & + & + \\
\hline Haemophilus influenzae type B & + & + & + & + & + & + & + & + & + & & + \\
\hline Hepatitis A & & & & & + & & + & & & & \\
\hline Hepatitis B & + & + & + & + & + & + & + & + & + & + & + \\
\hline Human papilloma virus & + & + & + & & & & + & + & + & & + \\
\hline Influenza & & & & & & & + & & & + & \\
\hline Meningococcal C & + & & + & & & & + & & + & & \\
\hline Morbilli & + & + & + & + & + & + & + & + & + & + & + \\
\hline Parotitis epidemica (mumps) & + & + & + & + & + & + & + & + & + & + & + \\
\hline Pertussis & + & + & + & + & + & + & + & + & + & & + \\
\hline Pneumoccocus & + & + & + & & + & & + & & + & & \\
\hline Poliomyelitis & + & + & + & + & + & + & + & + & + & + & + \\
\hline Rotavirus & + & & & & + & & + & & & & \\
\hline Rubella & + & + & + & + & + & + & + & + & + & + & + \\
\hline Tetanus & + & + & + & + & + & + & + & + & + & + & + \\
\hline Tick borne encephalitis & & $+^{*}$ & & & & & + & & & & \\
\hline Varicella & & + & + & & & & + & & & & \\
\hline \multicolumn{12}{|l|}{ Screenings } \\
\hline Autism ${ }^{\mathrm{b}}$ & & & + & + & + & + & & + & & & + \\
\hline Color blindness $^{\mathrm{d}}$ & + & + & + & & & + & + & + & & + & + \\
\hline Congenital defects ${ }^{\mathrm{c}}$ & + & + & + & + & + & + & + & + & + & & + \\
\hline Developmental coordination disorder ${ }^{\mathrm{c}}$ & & + & + & + & & + & + & + & & & + \\
\hline Developmental disabilities ${ }^{\mathrm{b}, \mathrm{c}}$ & + & + & + & + & + & + & + & + & + & & + \\
\hline Developmental dysplasia of the hip ${ }^{c}$ & + & + & + & + & + & + & + & + & + & & + \\
\hline Eating disorders ${ }^{\mathrm{e}}$ & + & + & + & + & + & + & + & + & & + & + \\
\hline Hearing screening ${ }^{\mathrm{d}}$ & + & + & + & + & + & + & + & + & + & + & + \\
\hline Maledescensus testis ${ }^{\mathrm{c}}$ & + & + & + & + & + & + & + & + & + & & + \\
\hline Neonatal bloodspot screening & + & + & + & + & + & + & + & + & + & & + \\
\hline Neonatal hearing screening & + & $?$ & + & + & + & + & + & + & + & & + \\
\hline Postpartum depression mother & & $?$ & + & + & + & & & + & & & + \\
\hline Scoliosis ${ }^{\mathrm{e}}$ & + & + & + & + & + & + & + & + & & + & + \\
\hline Speech and language disorders ${ }^{\mathrm{d}}$ & + & + & + & + & + & + & + & + & + & + & + \\
\hline Visual disorders & + & + & + & + & & + & + & + & + & + & + \\
\hline
\end{tabular}

$B E$ Belgium, $C H$ Switzerland, $D E$ Germany, EE Estonia, $F$ Finland, $H R$ Croatia, $H U$ Hungary, $M K$ FYR Macedonia, $N L$ Netherlands, $R U$ Russia, $S$ Slovenia

* Only in endemic areas

${ }^{\text {a }}$ Performed by doctors and/or nurses

b In preschoolers

${ }^{c}$ In infants

${ }^{d}$ In school children

e In adolescents 


\section{Discussion}

This international comparison shows that different models of YHC provision are being used in 11 of the 13 EUSUHM countries. Although different models are in use there are many similarities, particularly in the basic activities of YHC such as immunizations, monitoring and detection, screenings and epidemiological research. The main differences appeared in the target group and the separation of curative and preventive services.

A strength of our study is the inclusion of East European countries and the coverage of YHC services for all age groups from birth to 19 years. Recently a report on YHC in 37 member states of the WHO European Region was published. This report also includes East European countries but has a focus on governance, organizational aspects and service delivery of predominantly School Health Services (World Health Organization 2010).

Some limitations of our study need to be mentioned as well. Since YHC is a complex system, it was not possible to investigate every issue, which may have caused a loss of organizational aspects. Therefore, while the preliminary framework applied in this study proved to be useful in measuring the YHC characteristics of each country, the methodology needs further improvement.

Sending questionnaires to the EUSUHM representatives resulted in a high response. Respondents, all highly qualified health care professionals and chairs of (national) YHC organizations, were authorities on YHC in their country. Nevertheless, since only one respondent per country filled out the questionnaire (sometimes in consultation with colleagues) representing the whole country, this may have influenced the reliability of the results. Furthermore, despite verification of the results, the resources available to the respondents could not be traced back. Due to the sparse availability of comparative studies of YHC in different countries, only the study of Kuo et al. (2006) could be taken as a frame of reference.

When the above-mentioned limitations of the study are taken into account, this study should be interpreted as a preliminary step in mapping the organisational and practice features of YHC in Europe. The approach to YHC differs among the countries. Several elements of the program packages have been shown to have a favorable (cost)effectiveness (e.g., immunizations, certain screenings, prevention of cot death); other elements, e.g., health promotion programmes, have a social priority and are not (or not yet) evidence-based (Verloove-Vanhorick et al. 2003). More analytic research is needed to get detailed insights in the YHC of the examined and other European countries in relation to child health status and developmental outcomes. Through this, theoretical knowledge on how different care systems or different performance of health care activities affect health will increase. By performing future research and on basis of theoretical determinations, it may be possible to reach consensus on the structural and practice features that are essential for high quality YHC delivery in European countries.

Open Access This article is distributed under the terms of the Creative Commons Attribution Noncommercial License which permits any noncommercial use, distribution, and reproduction in any medium, provided the original author(s) and source are credited.

\section{References}

Bobak M, Marmot M (1996) East-west mortality divide and its potential explanations: proposed research agenda. BMJ 312:421-425

Child Health Knowledge Center (2010) Jeugdgezondheidszorg voor alle kinderen in Nederland (Youth health care for all children in the Netherlands). Ncj.nl. http://www.ncj.nl/onderwerpen/1/ jeugdgezondheidszorg. Accessed 21 Dec 2010

Christian CW, Sege RD (2010) The committee on injury, violence, and poison prevention and the council on community pediatrics. Policiy statement - Child fatality review. Pediatrics 126:592-596

European Society of Ambulatory Pediatrics (ESAP) (2006) What's about ambulatory pediatrics in Europe: reflections of ESAP. Geneva

EUSUHM (2004) Statutes of the EUSUHM. Eusuhm.org. http:// www.eusuhm.org/. Accessed 15 March 2009

Kuo AA, Inkelas M, Lotstein DS, Samson KM, Schor EL, Halfon N (2006) Rethinking well-child care in the United States: an international comparison. Pediatrics 118:1692-1702

Macinko J, Starfield S, Shi L (2003) The contribution of primary care systems to health outcomes within Organization for Economic Cooperation and Development (OECD) countries, 1970-1998. HSR 38(3):831-865

Ministry of Health, Welfare and Sport (Ministerie van Volksgezondheid, Welzijn en Sport) (2002) Basistakenpakket jeugdgezondheidszorg 0-19 jaar (National Youth Health Service Package 0-19 years). Ministry of Health Welfare and Sport, The Hague

Office of the United Nations High Commissioner for Human Rights (2004) Status of ratifications of the principal international human rights treaties. unhchr.ch. http://www.unhchr.ch/pdf/report.pdf. Accessed 29 July 2009

RIVM (2008) Dare to compare. Bohn Stafleu van Loghum, Bilthoven

Starfield B, Shi L, Macinko J (2005) Contribution of primary care to health systems and health. Milbank Quart 83(3):457-502

UN General Assembly (1989) Convention on the Rights of the Child. Treaty Series 1577:3. Unhchr.ch. http://www.unhchr.ch/html/ menu3/b/k2crc.htm. Accessed 26 July 2009

Vågerö D (2010) The east-west health divide in Europe: growing and shifting eastwards. European Review 18(1):23-34

Verloove-Vanhorick SP, Verkerk PH, van Leerdam FJM, Reijneveld SA, Hirasing RA (2003) Jeugdgezondheidszorg: veel preventie voor weinig geld [Youth health care: much prevention for little money]. Ned Tijdschr Geneeskd 147:895-898

World Health Organization (2005) European strategy for child and adolescent health and development. WHO Regional Office for Europe, Copenhagen

World Health Organization (2010) Pairing Children with Health Services. WHO Regional Office for Europe, Copenhagen

World Health Organization Regional Office for Europe (2009) European health for all database. Euro.who.int. http://data.euro. who.int/hfadb/. Accessed 3 June 2009 